\title{
Disability and vulnerability : a human rights reading of the responsive state
}

\section{Heikkilä, Mikaela}

2020-09-13

Heikkilä , M , Katsui , H \& Mustaniemi-Laakso , M 2020 , ' Disability and vulnerability : a human rights reading of the responsive state ' , The International Journal of Human Rights, vol. 24 , no. 8 , pp. 1180-1200 . https://doi.org/10.1080/13642987.2020.1715948

http://hdl.handle.net/10138/332515

https://doi.org/10.1080/13642987.2020.1715948

unspecified

acceptedVersion

Downloaded from Helda, University of Helsinki institutional repository.

This is an electronic reprint of the original article.

This reprint may differ from the original in pagination and typographic detail.

Please cite the original version. 


\title{
Disability and vulnerability: A human rights reading of the responsive state
}

\author{
Mikaela Heikkilä, Hisayo Katsui and Maija Mustaniemi-Laakso
}

(This article manuscript was accepted to the International Journal of Human Rights, and was published in 2020. Heikkilä, M., Katsui, H., \& Mustaniemi-Laakso, M. (2020). Disability and vulnerability: a human rights reading of the responsive state. The International Journal of Human Rights.https://doi.org/10.1080/13642987.2020.1715948)

\begin{abstract}
Universal human rights of all are complemented with particular, targeted protection of some, especially those that traditionally have been left behind. By juxtaposing the ideas of universality and particularity, the article studies vulnerability as a particularising tool within human rights with a comparative approach to the influential vulnerability theory by Martha Fineman. By outlining the similarities and the differences between the two approaches of vulnerability theory and human rights project, the article sheds light on how the particular protection needs of persons with disabilities play out in the universalistic logic of vulnerability. The article argues that both universal and particular obligations of responsive states - and responsive humans - are needed as a way of materialising substantive equality for persons with disabilities as vulnerable legal subjects. Such obligations cannot be codified in full detail, but the intrinsic essence of rights requires each right to be interpreted in context and with regard to the particular individual vulnerabilities and resilience of each person. In operationalising the obligations arising from such rights, the human rights project and the vulnerability theory complement and reinforce each other in terms of specifying the rationale and the detailed benchmarks for state action.
\end{abstract}

Keywords: disability, vulnerability, human rights, positive obligations, equality

\section{Introduction}

In recent times, one of the buzzwords in the human rights discourse (and beyond) has been 'vulnerability'. The expansion of vulnerability reasoning may be seen as indicative of a trend towards particularisation of human rights law, where universal human rights of all are complemented with special protection of some, especially those that traditionally have been left behind. The adoption of special measures of protection and/or of affirmative action to 
ensure substantive equality for persons with disabilities is an example of this. Interestingly, however, vulnerability as a concept is notoriously absent from the mainstream discussions on disability, probably due to the stigma that the notion is perceived to carry and the way it is seen to internalise and individualise disability as an ontological factor, thereby contributing to the normalisation of the existing power relations within societies (Clough, 2017).

The situation begs the question of the role and function of the vulnerability paradigm as a structural element of human rights in approaching disability. This chapter argues that much of this question essentially boils down to the interplay - or the contradiction, as one may put it (cf. Petman, 2009: 20)1 - between the universal and the particular in the human rights project. By juxtaposing the ideas of particularity and universality, the chapter studies vulnerability as a particularising tool within human rights with a comparative approach to the influential vulnerability theory by Martha Fineman. By outlining the similarities and the differences between the two approaches, the chapter sheds light on how the particular protection needs of persons with disabilities play out in the (universalistic) logic of vulnerability.

This chapter first explores how the human rights project has moved from the view of the human as an autonomous liberal subject to a more multifaceted understanding of the legal subject that recognises different degrees of autonomy and vulnerability. The way in which international human rights law approaches disability is a case in point exemplifying this development. From being something that is not really acknowledged at all, disability and impairment have in today's international human rights become to be recognised as factors that specify or particularise states' obligations towards individuals. Against this background, the chapter explores how the idea of a 'responsive state' has been framed within the two approaches and contemplates upon the relationship between the 'particularity' of an individual and the struggle for universality of resilience-building measures. Universality, it is submitted, does not exclude individualisation of the measures. Discussing examples drawn from the experiences of persons with disabilities, the chapter reasons that while state obligations are universal of their nature, that is, owed to all individuals in the same fashion, targeted special measures are needed to ensure the accessibility, adaptability, affordability and availability of societal structures to all persons with disabilities. In conclusion, it is submitted that valuable lessons on how to understand and address human vulnerability can be learnt both from the more theoretical

1 'Within the heart of human rights there lies a tension $[\ldots]$ : the tension between homogenization on the one hand and respect for pluralism and group difference on the other, between universalism and particularism'. 
framework of the vulnerability theory and the more hands-on approach to vulnerability in human rights law.

\section{Vulnerability and the move away from the idea of the liberal subject}

The changing view of the individual as the subject of law and protection

A core principle in international human rights law is that of universal application, emphasising the fact that human rights belong to everyone; we all hold the same universal rights (e.g. NifosiSutton, 2017: 28; Arnardóttir, 2009: 42). Historically, such universalism was largely built on the idea of the liberal subject capable of claiming his or her rights, the 'archetype of the autonomous, free-standing individual' (O’Cinneide, 2009: 170). For some time now, however, a clear shift in thinking has taken place within human rights law, with a growing realisation that whereas rights are universal and the same for everyone, there are groups and individuals who face particular challenges in having their human rights realised (cf. Gourevitch, 2009: 301). ${ }^{2}$ One such group is persons with disabilities whose human rights have often been denied both in law and in practice (Mégret, 2008: 500; Palacios and Walls, 2006: 128). This realisation of particular vulnerability has resulted in a shift in thinking through which more targeted measures and obligations have been put in place and are seen as a necessary element to the universal protection of rights. The resulting struggle for substantive equality through affirmative action is characteristic of the human rights project of today.

Within human rights law, substantive equality is pursued through a multi-lane approach. One such lane is to accommodate the special needs of vulnerable groups by interpreting general human rights instruments in a way that ensures attention to particular needs. In relation to disability, this is something that often has largely remained undone with disability traditionally remaining 'an invisible element of international human rights law' (Kayess and French, 2008: 12). Lately, however, various international courts and treaty bodies have started to pay more attention to disability and disability has been increasingly included as a topic in general comments and reporting regarding general human rights instruments (see, for example, General Comment 5, 1994; General Comment 9, 2006; Report, 2007). Through case law, the applicability of general human rights instruments to cases involving disability has also been clarified. For example, the European Court of Human Rights (ECtHR) has adopted an approach

\footnotetext{
2 Gourevitch argues that there has been a move away from a self-willing moral agent as the foundation of rights to a 'needy individual whose vital interests need protection'.
} 
that requires affirmative action from states to ensure substantive equality. ${ }^{3}$ Human rights treaties may also include provisions that attach specific attention to particular groups. Such a provision is, for example, Article 23 of the Convention on the Rights of the Child in which the States Parties recognise 'the right of the disabled child to special care'. ${ }^{4}$

Notably, special protection for particular groups is also sought for through a number of special human rights instruments or 'thematic conventions', which have as their aim to address particular protection needs and challenge the idea of the liberal subject that is automatically and autonomously capable of claiming his or her human rights. An example of such a groupspecific human rights instrument is the Convention on the Rights of Persons with Disabilities (CRPD) that was adopted in $2006 .{ }^{5}$ Given the fact that general human rights instruments, or their implementation, do not always fully accommodate the particular needs and experiences of some individuals, the special conventions such as the CRPD are seen to have a corrective function (Mégret, 2008: 497). 'These are the afterthoughts, provisions for specific groups of people who were not part of the original bargain and whose rights were thus felt, in the years to come, to be in need of special protection', as Petman notes (2009: 24). The CRPD's aim is hence to ensure that human rights are ensured in relation to persons with disabilities through 'tailor[ing] the existing suite of general human rights to the specific situation of persons with disabilities' (Quin,, 2009: 100).

Beside such special conventions and the interpretation of general human rights to the benefit of vulnerable individuals, special protection has in human rights law lately increasingly also been striven for through the utilisation of the concept of 'vulnerability'. The augmented use of the term in human rights law has sometimes even been seen as a sign of the 'vulnerabilisation' of the law (Ippolito and Sánchez, 2015: 5). ${ }^{6}$ An example of this is the rich vulnerability case law of the ECtHR, which the Court has developed in particular since the Chapman $v$ the United Kingdom case of 2001 recognising that the Roma should be given special protection due to their vulnerable position as a minority. ${ }^{7}$ Since Chapman, the ECtHR has recognised several

3 See, for example, ECHR Factsheet, n.d. The limits of the case law have, however, been emphasised by, for example, O’Cinneide, 2009: 180.

4 There are also many soft law instruments that are group-specific. Regarding persons with disabilities, see, for example, Declaration, 1975; Commission, 1998.

$5 \quad$ Other examples are: Convention on the Elimination of All Forms of Discrimination against Women (1979); Convention on the Rights of the Child (1989); International Convention on the Protection of the Rights of All Migrant Workers and Members of Their Families (1990).

$6 \quad$ Mégret, on his part, speaks of a 'pluralization trend', in which specific groups are recognised as 'worthy of a specific human rights protection (2008: 495).

$7 \quad$ Chapman v. the United Kingdom App. no. 27238/95 (ECtHR, 18 January 2001), para. 96. See also Peroni and Timmer, 2013: 1063. The word 'vulnerable' can, however, be found in some other earlier cases, 
other groups, including persons with disabilities, as particularly vulnerable. ${ }^{8}$ In Alajos Kiss v Hungary, for example, the ECtHR referred to persons with mental disabilities as 'a particularly vulnerable group in society'. ${ }^{9}$

It may be argued that the ECtHR's vulnerability case law functions according to the same logic as the special conventions. The underlying rationale for both is that special measures are sometimes needed for individuals to enjoy their human rights. Despite the increased focus on vulnerability in human rights law, the concept of 'vulnerability' has, however, remained rather elusive in the law, most notably in terms of its definition (e.g. Peroni and Timmer, 2013: 1064). From this perspective, it is interesting that around the same time as the ECtHR's vulnerability case law expanded, Professor Martha Albertson Fineman introduced her influential vulnerability theory, first published in 2008 (Fineman, 2008: 1-23). Fineman has herself explained the naissance of her theory as an originally a human rights theory for the American audience (Fineman, 2013: 13). ${ }^{10}$ In essence, also the vulnerability theory is a critique of the liberal subject as the foundation of law (e.g. Fineman, 2019: 355-6). According to Fineman, 'the abstract legal subject of liberal Western democracies fails to reflect the fundamental reality of the human condition' (Fineman, 2017: 133). In lieu of resting on the premise of the liberal autonomous individual, she argues, societal design and law should take as their starting point an understanding of human vulnerability as something universal and constant (ibid.: 134). In the same line of thought as the mechanisms for special protection within the human rights project, the theory thus directs criticism against a view of humans as self-sufficient and independent (ibid.: 139). Below, the ideas of vulnerability and dependence are explored further with an emphasis on vulnerability in the context of disability.

Changing paradigms of persons with disabilities as vulnerable subjects

Parallel to the recognition of the fact that special measures are needed to address vulnerability, the view on how we comprehend human particularity as such has undergone paradigmatic changes. This has happened at several fronts, but an especially interesting example is the development that has taken place in how we perceive persons with disabilities as vulnerable

\footnotetext{
but it was then used in a different context. For example, Dudgeon v. the United Kingdom App. no. 7525/76 (ECtHR, 22 October 1981).

$8 \quad$ For example, Alajos Kiss v. Hungary App. no. 38832/06 (ECtHR, 20 May 2010), para. 42; Zehentner v. Austria App. no. 20082/02 (ECtHR, 16 July 2009), para. 63; Renolde v. France App. no. 5608/05 (ECtHR, 16 October 2008), para. 109; and Fernandes de Oliviera v. Portugal App. no. 78103/14 (ECtHR, 31 January 2019), para. 113.

9 Alajos Kiss v. Hungary App. no. 38832/06 (ECtHR, 20 May 2010), para. 42.

10 Later on, Fineman, however, appears to distinguish her theory from human rights law by emphasising that the 'vulnerability approach is not centred on [ . . ] human [ .. ] rights' (Fineman, 2019: 342).
} 
subjects of the law. Understanding the global history of disability rights helps us to grasp these changes in the conceptualisation of the vulnerability of persons with disabilities over time and today.

For long, disability remained largely an invisible element of human rights law and it was not until 1975 that disability entered the mainstream human rights thinking with the Declaration on the Rights of Disabled Persons (UNGA, 1975). This was followed in 1982 by the publication of the World Programme of Action Concerning Disabled People (UNGA, 1982), which restated the distinction made between impairment, disability and handicap introduced by the World Health Organization in the 1970s. ${ }^{11}$ This medical model of disability represented a medically oriented understanding of disability, under which social disadvantages and vulnerabilities were considered to arise as a direct consequence of individual impairment (Barnes, 1991: 1-2.).

This approach to disability was extensively challenged by the disability community for individualising disability and victimising persons with disabilities, thereby stigmatising them (e.g. Goodley, 2014: 105-30; Grue, 2016: 957-64). It was argued that more than the medical 'facts' were needed in order to understand disability as a collective experience in society, which goes beyond the existence or experience of individual persons with disabilities. Out of this process emerged a social model of disability, which contests the very assumption of 'normality' and re-defines disability as a form of social oppression (French, 1994: 3-16). The term 'disabled people' was used to highlight and to politicise the fact that the society and its structures created disability. With the social model of disability, it was increasingly realised that disability arose from the way societies were organised, not from the individual difference or impairment. As a consequence, contextual factors became a more important focus than impairments to deconstruct social vulnerabilities and oppressions and the responsibility for the collective vulnerabilities of persons with disabilities was shifted to the society at large. This approach to the vulnerability of persons with disabilities is inherent also in the CRPD, which recognises disability as resulting 'from the interaction between persons with impairments and attitudinal and environmental barriers that hinders their full and effective participation in society on an equal basis with others'. ${ }^{12}$

\footnotetext{
11 Draft World Programme of Action Concerning Disabled Persons, UN Doc. A/37/351/Add. 1, 20 (para. 6). by the Committee on the Rights of Persons with Disabilities (see General Comment 6, 2018: paras 2, 8-9).
} 
The social model shares many of the elements that are also inherent in the theory on vulnerability by Fineman. Both of the approaches start from the premise that our understanding of vulnerability should transcend the idea of vulnerability as an identity category, to rather see it as something that gives rise to obligations upon the state and other actors to accommodate such vulnerability and difference. As noted above, for Fineman, vulnerability is something constant and universal, following from the fact that humans as embodied beings are continuously susceptible to change in their bodily (and social) well-being. That is, there is always a possibility for harm, injury and misfortune (e.g. Fineman, 2008: 9). ${ }^{13}$ In this way, the theory deconstructs the able-v. disabled binary (see further, Clough. 2017: 469-81; Knight, 2013: 15-26), much in line with the social model of disability.

In Fineman's theory, a corollary to or consequence of human vulnerability is dependency, of which there are two main kinds (Fineman, 2017: 134 and 139). So-called inevitable dependency, which, according to Fineman, is universal (Fineman, 2015a: 620), but manifests itself in the 'needs for care associated with certain biological and developmental stages of life' (Fineman, 2017: 139). This type of a 'physical or emotional dependence on others' is also, according to her, often present in connection to disability (ibid.: 145; Fineman, 2015a: 620). In addition to inevitable dependence, Fineman conceptualises derivative dependency, that is, 'burdens allocated to some societal roles or positions that operate to disadvantage the individuals who occupy them' and which is socially imposed (Fineman, 2015a: 620-1). The theory emphasises that we all experience dependence and lack of autonomy in the different phases of our lives. Such dependency should therefore not be regarded as something deviant, but as an inevitable aspect of being a human (ibid.: 622).

While Fineman's theory strongly focuses on the all-human vulnerability and dependence, it also acknowledges difference between individuals. According to Fineman, such difference arises as a result of humans being both embodied and social beings embedded in social institutions and relationships (Fineman, 2017: 143). As embodied beings, humans experience different developmental stages (such as childhood and the becoming of age) and, for example, disability (ibid.: 144). As social beings, on the other hand, we are 'differently situated within webs of economic, social, cultural, and institutional relationships that profoundly affect or destinies and fortunes' (ibid.: 145). Interestingly, the factors that result in relevant differences between individuals are very similar in Fineman's theory and in human rights case law. The ECtHR has characterised both certain persons as vulnerable (for example, persons with health

13 Scully refers to this as 'ontological vulnerability' of all human life (Scully, 2014: 204-5). 
issues and children), ${ }^{14}$ and, on the other hand, emphasised that sometimes individuals find themselves in vulnerable situations or positions. ${ }^{15}$ This corresponds to the difference between inherent/embodied and situational/embedded vulnerability that often is made with reference to Fineman's theory (see, for example, Mackenzie et al., 2014: 7. ${ }^{16}$ Regarding the latter, the ECtHR has, for example, given legal relevance to historical patterns of discrimination and stigma (see, for example, O’Boyle, 2015; Zimmermann, 2015: 540-1), as well as to particular situations of dependency. ${ }^{17}$ As such, also in general human rights law we can see a move towards a greater emphasis being put on the societal creation of vulnerability.

In sum, several shifts in thinking regarding both persons with disabilities as legal subjects, as well as the legal subject more in general have taken place over the years in the legal discourse. The liberal subject as a basis of laws and policies has at least partly been replaced with a more multifaceted understanding of the human condition in which vulnerability and dependence play a central role. Simultaneously, a move has taken place towards a greater emphasis on the disabling - and abling - contextual factors influencing our resilience and dependence as well as disability. With this in mind, a question arises as to what the consequences of such changes in our understanding of the legal subject are. How do such shifts affect the way we look at obligations incumbent on states in relation to addressing vulnerability of persons with disabilities?

\footnotetext{
14 For example, Rooman v. Belgium App. no. 18052/11 (ECtHR, 31 January 2019), para. 164 ('the applicant is a vulnerable individual on account of his health condition and his detention'). When talking of children, it is particularly common to refer to them as vulnerable individuals. For example, in the Popov v. France case, the ECtHR emphasised the 'child's extreme vulnerability' that was 'related in particular to their age and lack of independence'. Popov v. France App. no.s 39472/07 and 39474/07 (ECtHR, 19 January 2012), para. 91 .

$15 \quad$ For example, Kanciat v. Poland App. no. 37023/13 (ECtHR, 23 May 2019), para. 74 ('all persons under the control of the police or a similar authority, are in a situation of vulnerability'), and Mubilanzila Mayeka and Kaniki Mitunga v. Belgium App. no. 13178/03 (ECtHR, 12 October 2006), para. 55 ('applicant's position was characterised by her very young age' which was one of the factors that put her in 'an extremely vulnerable situation').

16 Fineman herself, however, maintains that there is only one type of vulnerability that related to our embodiment. She thus speaks about embodied and embedded differences (Fineman, 2017: 144; see also Fineman, 2015b). A similar point is made by Scully who finds that 'what have been thought of as special vulnerabilities' in fact can be seen as 'particular manifestations of a broad ontological vulnerability to do with being human' (Scully, 2014: 218).

17 For example, Salman v. Turkey App. no. 21986/93 (ECtHR, 27 June 2000), para. 99; Mehmet Ali Ayhan and Others v. Turkey App. nos 4536/06 and 53282/07 (ECtHR, 4 June 2019), para. 40; Kanciat v. Poland App. no. 37023/13 (ECtHR, 23 May 2019), para. 74; T.W. v. Malta App. no. 25644/94 (ECtHR, 29 April 1999, para. 43. Dependency may be due to both situational factors (for example, detention) and inherent factors (for example, age) (Zimmermann, 2015: 541).
} 


\section{The vulnerable subject and the responsive state: the rights-holder-duty-holder paradigms}

In the vulnerability theory, the most central consequence of the finding of universal vulnerability is the need for an active and responsive state that builds resilience. ${ }^{18}$ As per the vulnerability theory, resilience is 'what provides an individual with the means and ability to recover from harm, setbacks, and the misfortunes that affect our lives' (Fineman, 2017: 146). Societal institutions hold a prominent role in building such resilience and in 'lessening, ameliorating, and compensating for vulnerability' (Fineman, 2010: 269). Autonomy is possible but only with the support by institutions. Societal institutions provide individuals with different types of resilience-building assets: physical (e.g. housing and food); human (e.g. education); social (e.g. human networks); ecological (e.g. clean natural environment); and existential (e.g. religion and art) (ibid.: 270-1). In her theory, Fineman elaborates on how the different types of societal organisations and institutions affect human resilience, but state's role is seen as central. 'Many of the institutions providing resources that give us resilience can only be brought into legal existence through state mechanisms', Fineman notes (ibid.: 272).

Interestingly, while Fineman emphasises the role played by the state, she does not regard the law in the form of individual human/civil rights as central (Fineman, 2019: 342.). More specifically, she finds that the identity approach to equality that such legislation represents only has 'a limited view on what should constitute governmental responsibility in regard to social justice issues' (Fineman, 2010: 254). In other words, vulnerability theory rejects the idea of human rights as a viable ground for social justice and a responsive state due to its 'individually focused $[\ldots]$ agenda that emphasizes formal equality and celebrates individual liberty and choice', which, to Fineman 'complicates the idea that the state can undertake positive action to effect something called social, or collective, justice' (Fineman, 2019: 346; see also Fineman 2013: 13). According to the vulnerability theory, one must, instead, go beyond individualised rights-based arguments and demand more from societal institutions (Fineman, 2014: 311).

This position, it is argued, seems, however, to be focused on human rights as individual entitlements, and to emphasise the obligation to respect, that is, the obligation of states to 'refrain from acting in a way that unjustifiably interferes with [ ... ] rights' (Council of Europe, n.d.). At the same time, it appears to discount the flipside of rights, the strong elements of positive obligations inherent in each human right, operating not only ex post but most

\footnotetext{
18 Or to quote Fineman: 'The nature of human vulnerability forms the basis for a claim that the state must be more responsive to that vulnerability' (2010: 255-6).
} 
essentially also ex ante binding societies to take active measures towards the collective realisation of all individuals' rights, both at a universal and at a particular level. ${ }^{19}$ At the universal level this means, in essence, that states are to contribute to the resilience of individuals to resist their vulnerability through the realisation of their human rights.

While Fineman does not stress the role of rights in creating or upholding a responsive state, in the disability context rights hold a prominent role today. The move away from the medical approach to disability has meant a shift from a charity-based thinking to a rights-based thinking. In terms of law and policy, this means that persons with disabilities are recognised as full subjects of rights and as holders of their own rights. ${ }^{20}$ This is reflected, for instance, in Article 1 of the CRPD that stipulates that, the aim of the convention is to 'promote, protect and ensure the full and equal enjoyment of all human rights and fundamental freedoms by persons with disabilities'. In so doing, the CRPD emphasises that persons with disabilities are rights-holders whose human rights the signatory states abide to uphold. ${ }^{21}$ States carry positive and enhanced obligations with regard to realising the rights of persons with disabilities through appropriate legislative, administrative and other measures, including through amending or abolishing legislation or practices that discriminate against them, protecting against discrimination by non-state actors, taking measures to facilitate the development of universal design and spreading of accessible information and awareness-raising. By emphasising such positive obligations, the human rights-based approach to disability not only changed the role of persons with disabilities but also that of their counterparts, namely duty-bearers. In the human rightsbased model, duty-bearers are primarily the states that ratify the convention but also many others, including anybody involved in inter-personal relationships with persons with disabilities. $^{22}$

In sum, the role of the state in the human rights system, one may argue, corresponds very much with the idea of a responsive state in the vulnerability theory: 'one with a clear duty to

\footnotetext{
19 Human rights law fundamentally entails three different types of obligations for states: to respect, to protect and to fulfil human rights. What these obligations mean is summarised in the following way by the UN Office of the High Commissioner for Human Rights: 'The obligation to respect means that States must refrain from interfering with or curtailing the enjoyment of human rights. The obligation to protect requires States to protect individuals and groups against human rights abuses. The obligation to fulfil means that States must take positive action to facilitate the enjoyment of basic human rights' (Office of the High Commissioner for Human Rights, n.d.).

$20 \quad$ General Comment 6, 2018: para. 2.

21 For example, Kanter, 2007: 292; Quinn, 2009: 89-90. Palacios and Walls have referred to this legal development as a 'paradigm shift' (2006: 122).

22 O'Cinneide has noted that the Convention on the Rights of the Child 'contains similar positive obligations which establish individual rights in relationships of dependency’ (2009: 167).
} 
effectively ensure realistic equality of access and opportunity to society's resource-generating institutions for everyone regardless of their individual characteristics', as described by Fineman (Fineman, 2015a: 613). In this sense, the idea of universal vulnerability requiring a responsive state, one could claim, is embedded in the positive human rights obligations that the states have abided to under different regional and international human rights treaties. Resilience in the human rights language could thus be taken to denote the realisation of rights or the capacity to realise one's rights through a system that builds on an idea of a responsive state. A responsive state in human rights terms means that individuals can hold a state to account for its failures to abide by its human rights obligations in front of international and regional treaty body organs, human rights courts and national supervisory mechanisms. The responsive state as defined in the vulnerability theory and the state as a responsible human rights actor vis-à-vis individuals may, in other words share more common ground than often thought despite different approaches to the significance of individual rights. One could even argue that the differences may, in the end, be more in the semantics - in the vocabulary of vulnerability - than in the approach to the concept of the responsive state - or the state as a responsible human rights duty-holder - at large. In both approaches, social justice is in essence striven for 'through the legal creation and maintenance of just social institutions and relationships' (Fineman, 2019: 342; regarding the vulnerability theory).

\section{From theory to practice: what is expected of the responsive state?}

The vulnerability theory highlights that vulnerability is not something that arises from or at 'a moment of harm or injury', but that it entails a continuum of changing needs and dependencies over the 'the past, present and future' (Fineman, 2015a: 626; see also Fineman, 2019: 360-1). In Fineman's theory, this life-course perspective demands that 'state responsibility with regard to human vulnerability must be consistent across the life-course' (Fineman, 2017: 144.). ${ }^{23}$ Yet, while the theory recognises the changing needs of vulnerable individuals and the constant responsibility of the state, it does not go much in detail on what exactly is needed for building resilience, remaining on a rather abstract level of meta-level obligations. This is possibly a choice that derives from the context in which the vulnerability theory is developed, the American society, where a theory to highlight the state as a responsive actor as a counterreaction to the American individualism probably has its place.

23 Fineman is critical how parental rights have obscured the independent state responsibility for the wellbeing of children, and argues that childhood should not be seen as a period of diminished state responsibility. 
At the same time, one might argue, when taken from the level of the rationale to the more practical level of implementation, within, for example, some of the north-European welfare states, the argument of the responsive state may call for some more specificity in order to have added operational impact. ${ }^{24}$ In such contexts, as hinted above, the state is, by and large, (albeit often far from perfectly in practice) already assuming the role as a responsive state by guaranteeing as constitutional and human rights, assets and resources for universal well-being, including universal health coverage, universal free quality primary and secondary education available to all and a myriad of social benefits, coupled with proactive measures of accommodation to make such rights and benefits equally and effectively available to all on a (substantively) equal basis.

Fineman criticises human rights law for sometimes being 'abstract' (Fineman, 2017: 143). ${ }^{25}$ This, of course, holds true for many human rights norms. Within human rights law, the often abstract rights that can be found in treaties are, however, brought to an operational level through the detailed authoritative guidance on their implementation provided not only reactively by courts in individual cases but notably also proactively by regional and international treaty body organs in the form of general comments and concluding observations issued as a part of their monitoring role, as well as in the form of recommendations and orders by national human rights monitoring bodies such as the ombudsman system. As a consequence, human rights law includes clearly spelled-out obligations for states for accommodated measures towards the realisation of rights in the different stages and phases of dependency of the human life, from infancy to old age. ${ }^{26}$ Given the principle of dynamic treaty interpretation, ${ }^{27}$ such guidance and obligations are adapted to the changing realities and circumstances in time and place.

Through such operationalisation, human rights law has also been forced to address in-depth the question of how to approach different degrees and types of human vulnerability and special needs. To understand the similarities and the differences between the approaches to vulnerability within human rights law and in Fineman's theory, we therefore need to look more deeply into the question of how the two theories approach the question of particularity.

\footnotetext{
$24 \quad$ Cf. Kohn, 2014: 13 ('Vulnerability theory provides little guidance as to how to prioritize among vulnerable subjects when allocating limited financial resources and political capital. Indeed, it makes such differentiation more problematic by emphasizing the universality of vulnerability').

25 Fineman is particularly uncomfortable with the human rights focus on liberty and dignity. For Fineman, the trigger for state action is the embodied and embedded vulnerability, which, indeed, can be seen as a more tangible tenet for why we need a responsive state in general.

26 Regarding children, see, for example, the Convention on the Rights of the Child and the various general comments adopted by the Committee on the Rights of the Child.

$27 \quad$ Vienna Convention on the Law of Treaties (1969), art. 31.
} 


\section{Obligations owed to persons with disabilities: vulnerability as a trigger for differentiated state action}

Both the vulnerability theory and the human rights project build on the idea of universality. We are all equal in dignity and universal rights, postulates the human rights project. ${ }^{28} \mathrm{We}$ are all equally and universally vulnerable, suggests the vulnerability theory (for example, Fineman, 2017: 142). What both interlinks and differentiates the two schools of thought is, however, how they approach differentiation within universality and how this affects the measures that states are expected to take to ensure the well-being and dignity of human beings.

Within the vulnerability theory, the approach to universality is unconditional. For Fineman, vulnerability presents itself as universal and she rejects the idea that some people can be 'considered more or less vulnerable' or 'differently or uniquely vulnerable' (For example, Fineman, 2017: 142.). ${ }^{29}$ Instead, as described above, the theory focuses on how institutions and different institutional arrangements can affect and contribute to levels of resilience, to mitigate the inherent vulnerability that all individuals share. As Fineman states,

vulnerability approach is not centered on specific individuals or groups [ ... R Rather, addressing human vulnerability calls into focus what we share as human beings, what we should expect of the laws and the underlying social structures, and relationships that organize society and affect the lives of everyone within society.

((Fineman, 2019: 342)

In this way, the theory is based on a post-identity argument that distances itself from 'a typical individualized rights-based argument organized by the concept of impermissible discrimination based on identity categories such as sex, race, or ethnicity' (Fineman, 2014: $311)$.

In the context of human rights, on the other hand, vulnerability is often viewed as something particular, or as a continuum where people can be more or less or particularly vulnerable. While universality forms the underlying basis also for the human rights thought, the project includes, as we have seen above, a set of mechanisms to particularise human rights protection. Such

\footnotetext{
28 Universal Declaration of Human Rights (adopted 10 December 1948) UNGA Res 217 A(III) (UDHR) art. 1 .

29 Fineman's thinking appears to have undergone a slight shift in this regard as in some of her earlier writings, particularity was approached differently: 'While it is important to recognize that vulnerability is [ ... ] universal [ ... ], it is also necessary to simultaneously recognize that vulnerability must be understood as particular, varied, and unique at the individual level' (Fineman, 2015a: 618).
} 
mechanisms recognise the need to address the specific measures that are needed for individuals to be able to have their rights realised on an effectively equal basis with others. The special protection regimes and the concept of vulnerability enhance and specify the scope and content of existing obligations to that end. In this way, the particularisation mechanisms can be seen as an element of - or indeed, a precondition for - the universality of social justice. They work as 'an extraordinary safety mechanism in cases where "regular" protection is not enough to ensure the effective realization of rights' (Heikkilä and Mustaniemi-Laakso, 2019), allowing - and obligating - decision makers and judges to 'show particular vigilance' when adopting measures and assessing possible violations to ensure that the human rights are ensured effectively for all. $^{30}$

To address such special consideration needs, and gaps in the law, special human rights instruments, such as the CRPD, can contain both 'separate restatements of how rights apply to' the particular groups, but also 'different versions of the same rights, or possibly even slightly different rights' (Mégret, 2008: 497). ${ }^{31}$ More generally, O’Cinneide has argued that: 'the Convention is $[\ldots]$ notable for how it articulates and gives effect to a distinctive vision of the rights of the individual within society' (O'Cinneide 2009: 163-4). It, for example, contains a set of provisions on protection against violence emphasising that 'there is a situation of greater vulnerability or risk for persons with disability'. ${ }^{32}$

Also the ECtHR's jurisprudence indicates that the special consideration functions on a sliding scale basis, with 'extreme' or 'particular' vulnerability giving rise to enhanced obligations. ${ }^{33}$ While it is generally asserted that a finding of vulnerability does not create new human rights (e.g. Brandl and Czech, 2015: 253), vulnerability functions as a tool to interpret the existing rights in a way that provides the vulnerable individuals protection not only in books but in practice. Some authors have even submitted that vulnerability could function as a guiding principle when prioritising scarce resources making it possible for states to 'give preference to those whose needs they consider most pressing' (Peroni and Timmer, 2013: 1084; see also

30 Cf. V.D. and Others v. Russia App. no. $72931 / 10$ (ECtHR, 9 April 2019), para. 115.

31 When the CRPD was negotiated, an outspoken goal was not to create new 'disability rights', but rather to ensure that existing rights are fully implemented in relation to persons with disabilities. See, for example,

Palacios and Walls, 2006; Quinn, 2009: 100. Many scholars have, however, noted that the CRPD at the same time has entailed significant changes to existing law. For example, Kayess and French, 2008: 32; Mégret, 2008: 498, 503.

32 Palacios and Walls, 2006: 147. For example, CRPD art. 10, 11, 15-17.

33 Cf. V.D. and Others v. Russia App. no. 72931/10 (ECtHR, 9 April 2019), para. 115. As pointed out by Scully, this requires that one can differentiate 'normal' and 'special' vulnerability from each other (Scully, 2014: 204). Human rights law can be criticised for not providing clear criteria for how this differentiation should be done. 
Timmer, 2013: 163). In other words, the universality of rights translates into differentiated obligations to respond to the different grades and types of vulnerable situations that individuals may find themselves in.

In many cases where the ECtHR has made a finding of particular vulnerability, this has had an effect on the outcome of the case (see, however, O'Boyle, 2015: 9). The Court has, for example, often found that there is a need to attach 'special consideration' or to give 'special protection' to those identified as vulnerable. To illustrate, in Fernandes de Oliviera v Portugal the Court held that:

Where the authorities decide to place and keep in detention a person suffering from [sic] a mental illness, they should demonstrate special care in guaranteeing such conditions as correspond to the person's special needs resulting from his or her disability. ${ }^{34}$

Special measures may thus be necessary for the benefit of members of a vulnerable group to ensure equal access to particular rights. ${ }^{35}$ When adopting policies and legislation, states must also pay particular attention to vulnerability, as it may also affect a state's leeway of action (for discussion, see Peroni and Timmer, 2013: 1075-82). As noted in, for example, Alajos Kiss v Hungary concerning the denying of voting rights for persons with mental disabilities:

if a restriction on fundamental rights applies to a particularly vulnerable group in society, who have suffered considerable discrimination in the past [ ... ] then the State's margin of appreciation is substantially narrower and it must have very weighty reasons for the restrictions in question. ${ }^{36}$

Similarly, in Béláné Nagy v Hungary, the vulnerability finding had effects on the proportionality evaluation to the effect that the State could not change its system of disabilityrelated social-security benefits without considering the effects this had on the vulnerable group of disabled persons. ${ }^{37}$

$34 \quad$ Fernandes de Oliviera v. Portugal App. no. 78103/14 (ECtHR, 31 January 2019), para. 113.

35 For example, Popov v. France App. nos 39472/07 and 39474/07 (ECtHR, 19 January 2012), para. 91. See also Médecins du Monde - International v. France Complaint No 67/2011 (ECSR, 11 September 2012), para. 132.

36 Alajos Kiss v. Hungary App. no. 38832/06 (ECtHR, 20 May 2010), para. 42.

37 Béláné Nagy v. Hungary App. no. 53080/13 (ECtHR, 13 December 2016), paras 121-4. 
The 'universal' does not come without 'the particular'

In human rights, a finding of vulnerability carries, in other words, legal significance and may enhance or specify the obligations on the part of the state to address the special consideration needs of the differently vulnerable individuals. This has led some to argue that vulnerable persons are 'entitled to more favorable treatment than others' (Bossuyt, 2016: 730). This is, of course, partly true, but perhaps it would be more correct to say that vulnerable individuals are entitled to the same protection as everyone else? The measures that are needed to attain that level of protection may just differ from one person to another. Here lies also the main difference, we argue, between the formal and substantive conceptions of equality, as will be explained more in detail below.

One of the most eloquent examples of the particularised protection needs is inclusive education. Universal access to primary education was included as one of the goals of the Millennium Development Goals (MDGs) (Goal 2, UNGA, 2010). Yet, during and past the time of the MDGs, children and persons with disabilities were largely left behind, and the goal of universal primary education did not become a reality for children with disabilities. Millions of children with disabilities who were not in schools were identified (Groce and Trani, 2009: 1800). This was due to the fact that even when children with disabilities were physically integrated in schools, the schooling was not inclusive as such. Various particular measures were lacking to ensure the accessibility, adaptability, affordability and availability of the education. To attain these so-called four As of the right to education, measures such as accessible environment, assistive devices and/or support for children with physical disabilities, and sign language-based learning and communication possibilities for deaf children may be necessary, among other things (General Comment 4, 2016). Children with visual disabilities may need text enlargement devices, while children with intellectual disabilities may need easy-read materials and/or personalised assistance. Such measures for universal design of the lived-in infrastructures for all are a crucial strategy for an inclusive society and require attention to specific needs. These measures also form a core of the human rights-based approach to inclusive education (ibid.). The right to education is stipulated as a universal right for all children in several widely ratified global human rights instruments and the core of this right, access to public educational institutions and programmes on an effectively and de facto non-discriminatory basis constitutes a right that states are to take all efforts to realise, even in situations of considerable difficulty. ${ }^{38}$

38 Report of the United Nations High Commissioner for Human Rights (2015) [report on the protection of economic, social and cultural rights in situations of armed conflict, with a specific focus on the rights to health and to education], UN Doc. E/2015/59. 
Where such specific measures are not taken, and individuals are treated the same, as formally equal to each other, persons with disabilities experience de facto discrimination of their rights, as the experience presented below illustrates:

One day, my housemate in Uganda came home very exhausted. She uses a crutch for walking. She said she could not have lunch in her university because the classroom was located on the second floor and there was no elevator. It was difficult and took her a long time to get to the second floor for the lecture, which continued after the lunch break for 30 minutes. With only a 30-minute break, she did not have time to go down and find a restaurant, eat, and make it back up to the second floor. So she decided not to eat lunch.

(Katsui, 2009: 141-2)

When taken from the inter-personal to a societal level, this personal experience highlights the element of particularisation that is required for rights protection to be effective and universal in the sense that such protection is effectively available to everyone. Such particularisation may be done at a universal level through the universal design of 'products, environments, programmes and services', to make them usable by all people, regardless of whether they have a disability or not. ${ }^{39}$ When diverse needs of individuals are taken into account from the onset of the conference and lecture organisation, inclusiveness is in most cases relatively unproblematic to arrange (Guzmán et al., 2016: 20). In the example cited above, the event could simply have been organised on the first (ground) floor or in another building to be accessible for all including those with physical disabilities. At the societal level, such accommodation may require special consideration of different special needs, for example, when building, renovating and assessing the accessibility of educational environments (General Comment 4, 2016).

On the other hand, it is essential to note that individual needs are diverse and cannot be accommodated in one solution. Particularisation may, hence, be necessary also at an individual level. For instance, some prefer dim light due to their impairment, while others a bright one. Persons with disabilities without any intellectual disabilities might prefer self-determination, while persons with profound intellectual and multiple disabilities mostly and necessarily rely on proxies for making decisions on their behalf (Nieuwenhuijse et al., 2019: 261-71). For blind persons the existence of some threshold or different materials may be important in order to 
distinguish different places. Pedestrian roads can be distinguished from roads for cars by a small threshold for them to safely remain on the side of the pedestrian roads. Many wheelchair users, on the other hand, prefer not to have any threshold at all, not even a small one, to ease their mobility. Moreover, even where a suitable solution may be found to accommodate the needs of both wheelchair users and blind persons, the weather conditions during a particular day, such as snow, may change their personal needs altogether under the particular circumstances. Likewise, while having exactly the same impairments, a subjective right, such as the transportation service of a certain number of hours per month for persons with severe disabilities, is enough for some and insufficient for others due to personal differences (Adressit, 2014). These are just some examples among many of heterogeneity of personal needs of persons with disabilities vis-à-vis possible solutions.

Where individual interests collide, universal accessibility and social justice cannot be solved by one approach for all. This reality brings in particularisation at an individual level and obliges duty-bearers to provide reasonable accommodation, via, as formulated throughout and in particular in Article 2 of the CRPD, 'means necessary and appropriate modification and adjustments not imposing a disproportionate or undue burden, where needed in a particular case'. Such a human rights-based approach to disability pays attention to both collective and individual vulnerabilities of persons with disabilities. Inclusiveness may, in other words, require ensuring the protection of rights beyond the universal design. While obligations linked to ensuring the universal design of environments, products and programmes so that they are usable by all people operates ex ante, that is, proactively, the obligation of reasonable accommodation is an ex nunc duty. This means that 'accessibility must be built into systems and processes without regard to the need of a particular person with a disability, for example, to have access to a building, a service or a product, on an equal basis with others' (General Comment 6, 2018: para. 24(a)).

The social model of disability has been criticised for failing to sufficiently take into account various individual differences including physical and psychological conditions (Shakespeare, 2017: 20-1). The same comment, one could argue, may at least partly be relevant for the vulnerability theory, which has a strong focus on the universality of vulnerability. Some elements of particularisation - albeit in a less outspoken way - figure, however, also in connection to the vulnerability theory. Such particularisation takes place in the form of particularisation of duties, not of vulnerability as such, unlike in human rights. This is visible, for example, in how Fineman approaches differences between individuals resulting from societal structures. Addressing such difference is, according to her, vital to underline the role 
of the responsive state in ensuring effective equality of opportunity and equal access to the resource-generating institutions for all irrespective of their individual characteristics (Fineman, 2015a: 612-13).

The vulnerability theory acknowledges hence that people experience vulnerability differently and that people are differently resilient to their vulnerability, which gives rise to differentiated obligations on the part of the responsive state. One may even go as far as argue that the different levels of resilience in the theory may actually conceptually correspond, at any rate to a certain degree, to the different levels of vulnerability in human rights giving rise to different obligations. Where the approaches differ, however, as noted above, is in the level of particularity in terms of the measures that are expected of the responsive state with regard to the operationalisation (similarly Kohn, 2014: 11, 13.). In human rights, such particular guidance is provided, for example, through the implementation, monitoring and coordination mechanisms stipulated in Article 33 of the CRPD. Interestingly, however, while the vulnerability theory at large rejects the group- or identity-based approach to vulnerability, it seems that it is open to somewhat of a more targeted approach when it comes to the operationalisation of the theory's tenets, for example, with regard to the elderly (Kohn, 2014: 11; see also Fineman, 2012: 84).

\section{Concluding remarks}

The personal story quoted above of the person with disability facing hurdles in accessibility in an educational environment is not exceptional and it vividly informs us of the obligations states and other duty-holders have in relation to the particular needs of individuals. A principal concern arising from such experiences is the attitude of those without a disability towards their peers with disabilities, leaving them behind, as if the problem was to be solved by the persons with disabilities alone. The peers and stakeholders at the event referred to perhaps did not mean to directly discriminate on the basis of disability. Formally equal treatment without paying careful attention to particularities, however, was the problem. Three points arise from this example and from the above discussion, with a linkage to the particularity-universality paradigm that forms the focus of this chapter. All three of them relate, in essence, to how the notion of vulnerability can function both to empower and to disempower persons with disabilities.

The first point has to do with how the understanding of vulnerability as universal as opposed to particular affects power relations within societies. As outlined above, human rights law contains obligations to make 'products, environments, programmes and services' usable by all 
people, regardless of whether they have a disability or not. ${ }^{40}$ Yet, the practical implementation of rights is still often insufficient, something that affects the way persons with disabilities can access their rights in practice, even where a relatively solid legal framework is in place ensuring equal rights of persons with disabilities. This is often due to the fact that personalisation of problems faced by persons with disabilities is still widely practised and remains deeply rooted in the mind-set of persons without a disability, hence continuing to sustain the predominant tradition of the medical model of disability. The widespread mentality of society is also often internalised by persons with disabilities, which further reinforces the normalisation of exclusion of persons with disabilities (Katsui, 2005: 84-91). This is a concern that is also raised in the recent General Comment to the CRPD on equality, regretting that the persisting charity/medical models refrain persons with disabilities from being seen as 'full subjects of rights and as rights holders' (General Comment 6, 2018: para. 2).

Fineman's theory on universal vulnerability holds great potential in addressing this kind of attitudinal barriers towards vulnerability and persons with disabilities. When we acknowledge that we are all universally and inherently vulnerable, and that we all need special protection in different phases of our lives, the stigma of vulnerability is likely to diminish. Through its markedly siloed understanding of vulnerability, defining certain groups of individuals as vulnerable, rights-based approaches have been criticised for failing to sufficiently recognise such lacking structural transformation needed for the empowerment of persons with disabilities (see, for example, Katsui, 2012; Katsui et al., 2016: 187-98.). In this light, the vulnerability theory is important in further highlighting the significance of a structural approach to vulnerability, an approach that starts off not with the characteristics of an individual but with the structures, power relations and lived-in-environments in order to identify and to address discriminatory elements in them (for example, Fineman, 2019: 367-8). While the CRPD takes an important step forward in addressing power relations within societies through its focus not only on state-individual but also on inter-personal relationships, ${ }^{41}$ this development within human rights law overall is, however, embryonic. One of the vulnerability theory's strengths is therefore, undoubtedly, its stronger focus on such relationships.

The second point that arises from the article relates to the operationalisation of the idea of universal vulnerability. While Fineman's vulnerability theory makes a strong case for a responsive state, it is not very outspoken as it comes to the specific measures the state should

\footnotetext{
$40 \quad$ CRPD, art. 2.

41 CRPD, Preamble ('Realizing that the individual, having duties to other individuals and to the community to which he or she belongs') and art. 26(1).
} 
take to that end. This is probably partly explained by the fact that for Fineman, the focus lies in the 'human', not the 'rights' part of the law (Fineman, 2019: 13). In light of this, the theory stresses the need to re-conceptualise the vulnerable human and to more generally change our perspective on the role of the state. Within human rights law, on the other hand, the need for a responsive state is taken for granted, and the emphasis is more on the realisation of such a state. In this context, the individual rights are central as they function as 'watchdogs' for the responsive state or, in human rights terms, the responsible state. The often-abstract human rights found in treaties have through different forms of treaty body practice been developed into more concrete state obligations to realise the various human rights, particularising the obligations for the reasonable accommodation where needed. Perhaps, in other words, it is exactly here where the most fundamental difference in the approach towards the responsive state between the human rights school and the vulnerability theory lies: in the level of specificity and the particularity of the measures that are expected of the responsive state. In this article, it was suggested that such particularity is a key element in the operationalisation of an effectively universal approach to vulnerability and rights protection.

Third, the two schools appear to differ in their approach to individual agency. In the vulnerability theory, the emphasis is, as noted above, markedly on the societal power and care relationships, which at the same time, seems to a certain degree to overshadow the significance attached to the agency of the vulnerable individuals and the need to empower them. According to the vulnerability theory, 'recognition of vulnerability does NOT reflect or assert the absence or impossibility of agency' (Fineman, 2015b). Yet, where persons with disabilities primarily are addressed through a caretaker-care receiver paradigm (cf. Fineman, 2017: 139), the voices of the persons with disabilities are typically not put in the limelight. Understandably, this difference probably is simply a question of focus but is worth pointing out given the importance of the issue. Within human rights law the question of agency of all individuals has become vital and recognising persons with disabilities as agents of their own rights is seen as crucial (for example, Quinn, 2009: 90). The CRPD also opens up alternative ways of conceptualising agency, given that persons with disabilities are highly heterogeneous and their vulnerabilities are diverse. Some persons with disabilities embrace the expected role of active, independent subjects, while for others, such as for persons with profound intellectual and multiple disabilities, the realisation of agency, or co-agency with proxies, presupposes careful measures and thorough understanding of their needs by the responsive states and responsive humans alike. Such differentiation builds, again, on the idea of particularised protection needed for substantive equality to be realised. 
In sum, there are many similarities between the vulnerability theory and the human rights approach to vulnerability, but also some significant differences. Both approaches acknowledge the duty of the state to respond to the universally shared needs of the individual, although the vocabulary to express such needs differs between the two projects. Both of them also recognise the importance of the societal structures in addressing human vulnerability and ensuring social justice. Based on the above analysis of vulnerabilities of persons with disabilities and the comparative analysis of the vulnerability theory and the human rights project, this chapter argues that both universal and particular obligations of responsive states are needed as a way of materialising substantive equality for persons with disabilities as vulnerable legal subjects. Such obligations cannot be codified in full detail, but the intrinsic essence of rights requires each right to be interpreted in context and with regard to the particular individual vulnerabilities and resilience of each person. In operationalising the obligations arising from such rights, the human rights project and the vulnerability theory complement and reinforce each other in terms of specifying the rationale and the detailed benchmarks for state action.

\section{References}

Adressit. (2014) Muutos vammaispalvelun myöntämiin taksimatkoihin. Available at https://www.adressit.com/muutosmatkoihin (accessed 23 October 2019).

Arnardóttir, Oddný Mjöll. (2009) A Future of Multidimensional Disadvantage Equality? In The UN Convention on the Rights of Persons with Disabilities: European and Scandinavian Perspectives, ed. Oddný Mjöll Arnardóttir and Gerard Quinn. Leiden: Martinus Nijhoff Publishers.

Barnes, Colin. (1991) Disabled People in Britain and Discrimination. London: Hurst.

Bossuyt, Marc. (2016) Categorical Rights and Vulnerable Groups: Moving Away from the Universal Human Being. George Washington International Law Review 48: 730.

Brandl, Ulrike and Czech, Philip. (2015) General and Specific Vulnerability of ProtectionSeekers in the EU: Is There an Adequate Response to Their Needs? In Protecting Vulnerable Groups: The European Human Rights Framework, ed. Francesca Ippolito and Sara Iglesias Sánchez. Oxford: Hart.

Clough, Beverley. (2017) Disability and Vulnerability: Challenging the Capacity/Incapacity Binary. Social Policy and Society 16(3): 474-6.

Commission. (1998) Commission on Human Rights Resolution 1998/31, Human Rights of Persons with Disabilities, 17 April. Geneva. 
M. Heikkilä, H. Katsui and M. Mustaniemi-Laakso

Council of Europe. (n.d.) Some Definitions. Available at https://www.coe.int/en/web/echrtoolkit/definitions (accessed 23 October 2019).

Declaration. (1975) Declaration on the Rights of Disabled Persons, General Assembly resolution 3447 (XXX), 9 December.

ECHR Factsheet. (n.d.) Persons with Disabilities and the European Convention on Human Rights. Available at https://www.echr.coe.int/Documents/FS_Disabled_ENG.pdf (accessed 23 October 2019).

Fineman, Martha Albertson. (2008) The Vulnerable Subject: Anchoring Equality in the Human Condition. Yale Journal of Law \& Feminism 20(1): 1-23.

Fineman, Martha Albertson. (2010) The Vulnerable Subject and the Responsive State. Emory Law Journal 60(2): 255-6.

Fineman, Martha Albertson. (2012) "Elderly" as Vulnerable: Rethinking the Nature of Individual and Societal Responsibility. Elder Law Journal 20: 84.

Fineman, Martha Albertson. (2013) 'Equality, Autonomy, and the Vulnerable Subject in Law and Politics', in Vulnerability: Reflections on a New Ethical Foundation for Law and Politics, ed. Martha Albertson Fineman and Anna Grear. Farnham: Ashgate.

Fineman, Martha Albertson. (2014) Vulnerability, Resilience, and LGBT Youth. Temple Political \& Civil Rights Law Review 23: 311.

Fineman, Martha Albertson. (2015a) Equality and Difference - The Restrained State. Alabama Law Review 66(3): 620.

Fineman, Martha Albertson. (2015b) Fineman on Vulnerability and Law. New Legal Realism, 30 November. Available at http://newlegalrealism.org/2015/11/30/fineman-onvulnerability-and-law (accessed 23 October 2019).

Fineman, Martha Albertson. (2017) Vulnerability and Inevitable Inequality. Oslo Law Review 4(3): 133.

Fineman, Martha Albertson. (2019) Vulnerability and Social Justice. Valparaiso University Law Review 53(2): 342.

French, Sally. (1994) What Is Disability? In On Equal Terms: Working with Disabled People, ed. Sally French. Oxford: Butterworth-Heinemann, 3-16.

General Comment 4. (2016) Committee on the Rights of Persons with Disabilities, General Comment No. 4 on the Right to Inclusive Education. 25 November. UN Doc. $\mathrm{CRPD} / \mathrm{C} / \mathrm{GC} / 4$.

General Comment 5. (1994) General Comment No. 5 of Committee on Economic, Social and Cultural Rights on Disability. 
General Comment 6. (2018) General Comment No. 6 on Equality and Non-Discrimination. UN Doc. CRPD/C/GC/6, 26 April.

General Comment 9. (2006) CRC General Comment No. 9 (206). The Rights of Children with Disabilities, CRC/C/GC/9, 29 September.

Goodley, Dan. (2014) Against a Politics of Victimisation: Disability Culture and SelfAdvocates with Learning Difficulties. In Disability, Culture and Identity, ed. Sheila Riddle and Nick Watson. Abingdon: Routledge, 105-30.

Groce, Nora Ellen and Trani, Jean-François. (2009) Millennium Development Goals and People with Disabilities. The Lancet 374: 1800.

Grue, Jan. (2016) The Social Meaning of Disability: A Reflection on Categorisation, Stigma and Identity. Sociology of Health and Illness 38(6): 957-64.

Guzmán, Nathaly Huuhtanen, Sari, Katsui, Hisayo, Kilpelä, Niina Koistinen, Mari, Pesola, Kirsti and Tuure, Tuomas. (2016) Inclusive WASH Activities in the Global South, 20. Available at https://www.vammaiskumppanuus.fi/wpcontent/uploads/2016/05/Inclusive_WASH_Activities_in_the_Global_South.pdf (accessed 23 October 2019).

Heikkilä, Mikaela and Mustaniemi-Laakso, Maija. (2019) Vulnerability as a Human Rights Variable: African and European Approaches. Unpublished seminar paper, Afridoors 3, Towards a More Robust Protection of Human Rights in Africa. Addis Ababa, Ethiopia, 7-11 October.

Kanter, Arlene S. (2007) The Promise and Challenge of the United Nations Convention on the Rights of Persons with Disabilities. Syracuse Journal of International Law and Commerce 34(2).

Katsui, Hisayo. (2005) Towards Equality: Creation of the Disability Movement in Central Asia. Helsinki: University of Helsinki.

Katsui, Hisayo. (2009) Towards Participation of Persons with Disabilities from the South: Implications of Article 32 of the Convention. In United Nations Convention on the Rights of Persons with Disabilities: Multidisciplinary Perspectives, ed. Jukka Kumpuvuori and Martin Scheinin. Helsinki: VIKE, 141-2.

Katsui, Hisayo. (2009) Disabilities, Human Rights and International Cooperation: Human Rights-Based Approach and Lived Experiences of Ugandan Women with Disabilities. Helsinki: VIKE. 
Katsui, Hisayo, Lehtomäki, Elina, Malle, Abebe Yehualawork and Chalklen, Shuaib. (2016) Questioning Human Rights: The Case of Education for Children and Youth with Disabilities in Ethiopia. In Disability in the Global South: The Critical Handbook, ed. Shaun Grech and Karen Soldatic. Cham, Switzerland: Springer, 187-98.

Kayess, Rosemary and French, Phillip. (2008) Out of Darkness into Light? Introducing the Convention on the Rights of Persons with Disabilities. Human Rights Law Review 8(1).

Knight, Amber. (2013) Disability as Vulnerability: Redistributing Precariousness in Democratic Ways. The Journal of Politics 76(1): 15-26.

Kohn, Nina A. (2014) Vulnerability Theory and the Role of Government. Yale Journal of Law \& Feminism 26(1): 13.

Mackenzie, Catriona, Rogers, Wendy and Dodds, Susan. (2014) Introduction: What Is Vulnerability, and Why Does It Matter for Moral Theory? In Vulnerability: New Essays in Ethics and Feminist Philosophy, ed. Catriona Mackenzie, Wendy Rogers and Susan Dodds. Oxford: Oxford University Press.

Mégret, Frédéric. (2008) The Disabilities Convention: Human Rights of Persons with Disabilities or Disability Rights. Human Rights Quarterly 30(2): 500.

Nieuwenhuijse, Appolonia M., Willems, Dick L., van Goudoever, Johannes B., Echteld, Michael A. and Olsman, Erik. (2019) Quality of Life of Persons with Profound Intellectual and Multiple Disabilities: A Narrative Literature Review of Concepts, Assessment Methods and Assessors. Journal of Intellectual and Developmental Disability 44(3): 261-71.

Nifosi-Sutton, Ingrid. (2017) The Protection of Vulnerable Groups under International Human Rights Law. London: Routledge.

O'Boyle, Michael. (2015) The Notion of "Vulnerable Groups" in the Case Law of the European Court of Human Rights. Report presented at the Conference on the Constitutional Protection of Vulnerable Groups: A Judicial Dialogue organized 4-5 December, Santiago, Chile. Available at https://www.venice.coe.int/webforms/documents/?pdf=CDL-LA(2016)003-e (accessed 23 October 2019).

O’Cinneide, Colm. (2009) Extracting Protection for the Rights of Persons with Disabilities from Human Rights Frameworks: Established Limits and New Possibilities. In The UN Convention on the Rights of Persons with Disabilities: European and Scandinavian Perspectives, ed. Oddný Mjöll Arnardóttir and Gerard Quinn. Leiden: Martinus Nijhoff Publishers. 
Office of the High Commissioner for Human Rights. (n.d.) International Human Rights Law. Available at https://www.ohchr.org/en/professionalinterest/pages/internationallaw.aspx (accessed 23 October 2019).

Palacios, Agustina and Walls, Maria. (2006) Changing the Paradigm - The Potential Impact of the United Nations Convention on the Rights of Persons with Disabilities. Irish Yearbook of International Law 1: 128.

Peroni, Lourdes and Timmer, Alexandra. (2013) Vulnerable Groups: The Promise of an Emerging Concept in European Human Rights Convention Law. International Journal of Constitutional Law 11(4): 1063.

Petman, Jarna (2009) The Special Reaching for the Universal: Why a Special Convention for Persons with Disabilities? In United Nations Convention on the Rights of Persons with Disabilities - Multidisciplinary Perspectives, ed. Jukka Kumpuvuori and Martin Scheinin. Helsinki: VIKE.

Quinn, Gerard. (2009) A Short Guide to the United Nations Convention on the Rights of Persons with Disabilities. European Yearbook of Disability Law 1: 100.

Report (2007) Report of the Special Rapporteur on the Right to Education (Vernor Munoz), The Right to Education of Persons with Disabilities, A/HRC/4/29, 19 February.

Scully, Jackie Leach. (2014) Disability and Vulnerability: On Bodies, Dependence, and Power. In Vulnerability: New Essays in Ethics and Feminist Philosophy, ed. Catriona Mackenzie, Wendy Rogers and Susan Dodds. Oxford: Oxford University Press.

Shakespeare, Tom. (2017) Disability: The Basics. London: Routledge.

Timmer, Alexandra. (2013) A Quiet Revolution: Vulnerability in the European Court of Human Rights. In Vulnerability: Reflections on a New Ethical Foundation for Law and Politics, ed. Martha Albertson Fineman and Anna Grear. Farnham: Routledge, 2013.

UNGA. (1975) Declaration on the Rights of Disabled Persons (adopted 9 December, UNGA Res $3447(\mathrm{XXX}))$.

UNGA. (1982) World Programme of Action Concerning Disabled Persons (3 December). UN Doc. A/RES/37/52.

UNGA. (2010) Resolution Adopted by the General Assembly on 22 September 2010 (19 October). UN Doc. A/RES/65/1.

Zimmermann, Nesa. (2015) Legislating for the Vulnerable? Special Duties under the European Convention on Human Rights. Swiss Review of International and European Law 25: $540-1$. 